\title{
Detection of Shiga toxin-producing Escherichia coli by sandwich enzyme-linked immunosorbent assay using chicken egg yolk IgY antibodies
}

\section{Y. R. Parma ${ }^{1,2 *}$, P. A. Chacana ${ }^{3}$, P. M. A. Lucchesi ${ }^{2,4}$, A. Rogé ${ }^{5}$, C. V. Granobles Velandia ${ }^{2,4}$, A. Krüger ${ }^{2,4}$, A. E. Parma ${ }^{4}$ and M. E. Fernández-Miyakawa ${ }^{1,2}$}

\author{
Instituto de Patobiología, Centro Nacional de Investigaciones Agropecuarias, Instituto Nacional de Tecnología Agropecuaria, Calle Las Cabañas y Los \\ Reseros s/n, Casilla de Correo 25 (1712), Castelar, Buenos Aires, Argentina \\ 2 CONICET, Buenos Aires, Argentina \\ ${ }^{3}$ IncuINTA, Instituto de Virología, Centro Nacional de Investigaciones Agropecuarias, Instituto Nacional de Tecnología Agropecuaria, Calle Las Cabañas y Los \\ Reseros s/n, Casilla de Correo 25 (1712), Castelar, Buenos Aires, Argentina \\ ${ }^{4}$ Lab. Inmunoquímica y Biotecnología, Depto. Sanidad Animal y Medicina Preventiva, Fac. Cs. Veterinarias, Universidad Nacional del Centro Pcia. Buenos Aires, \\ Tandil, Argentina \\ ${ }^{5}$ Servicio Sueros y Antígenos-Instituto Nacional de Producción de Biológicos ANLIS "Dr. Carlos G. Malbrán", Av. Vélez Sarsfield 563 (C1282AFF), Buenos Aires, \\ Argentina
}

\section{Edited by:}

Nora L. Padola, Universidad Nacional del Centro de la Provincia de

Buenos Aires, Argentina

\section{Reviewed by:}

Glen D. Armstrong, University of

Calgary, Canada

Marina S. Palermo, National Council

of Scientific and Technical Research,

Argentina

\section{*Correspondence:}

Y. R. Parma, Instituto de

Patobiología, Centro Nacional de Investigaciones Agropecuarias, Instituto Nacional de Tecnología Agropecuaria, Calle Las Cabañas y Los Reseros s/n, Casilla de Correo 25 (1712), Castelar, Buenos Aires, Argentina.

e-mail:yparma@cnia.inta.gov.ar
Enterohemorrhagic Escherichia coli (EHEC), a subset of Shiga toxin producing E. coli (STEC) is associated with a spectrum of diseases that includes diarrhea, hemorrhagic colitis and a life-threatening hemolytic-uremic syndrome (HUS). Regardless of serotype, Shiga toxins (Stx 1 and/or Stx2) are uniformly expressed by all EHEC, and so exploitable targets for laboratory diagnosis of these pathogens. In this study, a sandwich ELISA for determination of Shiga toxin (Stx) was developed using anti-Stx2B subunit antibodies and its performance was compared with that of the Vero cell assay and a commercial immunoassay kit. Chicken IgY was used as capture antibody and a HRP-conjugated rabbit IgG as the detection antibody. The anti-Stx2B IgY was harvested from eggs laid by hens immunized with a recombinant protein fragment. Several parameters were tested in order to optimize the sandwich ELISA assay, including concentration of antibodies, type and concentration of blocking agent, and incubation temperatures. Supernatants from 42 STEC strains of different serotypes and stx variants, including stX $x_{2 E D L 933}, s t x_{2 v h a}, s t x_{2 v h b}, s t x_{2 g}$, st $x_{1 E D L 933}$, and $s t x_{1 d}$ were tested. All Stx variants were detected by the sandwich ELISA, with a detection limit of $115 \mathrm{ng} / \mathrm{ml}$ Stx2. Twenty three strains negative for stx genes, including different bacteria species, showed no activity in Vero cell assay and produced negative results in ELISA, except for two strains. Our results show that anti-Stx2B IgY sandwich ELISA could be used in routine diagnosis as a rapid, specific and economic method for detection of Shiga toxin-producing E. coli.

\section{INTRODUCTION}

Enterohemorrhagic Escherichia coli (EHEC) causes a spectrum of human diseases ranging from mild non-bloody diarrhea through hemorrhagic colitis to the extraintestinal manifestation hemolytic-uremic syndrome (HUS) (Griffin and Tauxe, 1991). The incidence of HUS in Argentina is one of the highest in the world, with approximately 500 new cases being observed each year in under-5-year-old children (Rivas et al., 2010). Also, it is the leading cause of acute renal failure in pediatric age and the second for chronic renal failure (Exeni, 2001). Prompt and accurate diagnosis of Shiga toxin producing $E$. coli (STEC) infection is important to achieve an appropriate and early supportive treatment in the course of infection to decrease renal damage and improve overall patient outcome (Ake et al., 2005).

Shiga toxins (Stxs) are thought to be the major virulence factor of STEC strains (Tarr et al., 2005) and comprise a family composed of Stx1, Stx2, and their variants, which can be found in
STEC strains isolated from either humans or animals (Ito et al., 1990). Stx2, which is $56 \%$ homologous to Stx 1 at the amino acid sequence level, is clinically the most important Stx type, because it is associated with severe outcomes of human infections including HUS (Friedrich et al., 2002; Brooks et al., 2005). Stxs consist of a single A subunit, with catalytic activity, linked to a ring of five B subunits, responsible for specific cell binding of the toxin (O'Brien and Holmes, 1987).

The expression of Stx is characteristic of STEC strains and so, exploitable targets for laboratory diagnosis of these pathogens. Numerous assays for the diagnosis of STEC have been developed including microbiological, immunological, and genetical methods (Bettelheim and Beutin, 2003). Cytotoxicity assays are the most sensitive methods for detecting active Stxs (Paton and Paton, 1998) and have been used as "gold standard" for evaluation of immunological tests. However, this technique is expensive, labor-intensive, and time consuming and so, not often established 
for routine diagnosis. Stx-specific PCR detects gene sequences whether or not they are expressed (Bettelheim and Beutin, 2003). Stx-specific ELISA is a rapid, easy to perform and applicable technique for routine diagnosis, with a growing number of Stxdetection test kits offered by several companies (Scheutz et al., 2001). Compared to cytotoxicity assays or PCR, ELISAs are less sensitive (Beutin et al., 1996, 1997; Gerritzen, 1998) and not suitable to evaluate samples where low amounts of Stx are expected, such as mixed cultures and certain Stx2 variants (Ball et al., 1996; Beutin et al., 1996, 2007). These commercial kits are also economically unaffordable for use in developing countries. A lower cost alternative are ELISA assays based on the use of egg yolk antibodies (IgY) from laying hens and obtained in a non-invasive way. IgY is the typical low-molecular-weight egg yolk antibody of birds, reptiles, amphibians, and lungfish, whereas IgG occurs in mammals (Hardin et al., 2001). Because of the evolutionary distance between birds and mammals, a chicken is often a better choice for antibody production than a mammal when the antigen is of human or other mammalian origin (Schade et al., 2005). IgY also has the advantage to avoid the interference caused by the complement system, rheumatoid factors, anti-mouse IgG antibodies or human and bacterial Fc receptors in immunological assays. In addition, there is a minimal or no cross-reaction with mammalian IgG (Ambrosius and Hadge, 1987; Larsson and Sjoquist, 1990). Therefore, this study was intended to develop a sandwich ELISA using IgY as the capture antibody and a rabbit IgG as the detection antibody for determination of Shiga toxins in culture supernatants as a potential affordable research and diagnostic tool.

\section{MATERIALS AND METHODS PRODUCTION OF RECOMBINANT Stx2B}

Stx2B subunit was produced as previously described (Parma et al., 2011). Briefly, a DNA fragment encoding Stx2B was obtained by PCR amplification using DNA extracted from the reference strain E. coli EDL933. For expression of recombinant Stx2B subunit, transformed BL21-AI ${ }^{\mathrm{TM}}$ E. coli cells were grown in Luria-Bertani (LB) broth supplemented with $100 \mu \mathrm{g} / \mathrm{mL}$ ampicillin (Sigma Aldrich) and induced overnight with $0.2 \% \mathrm{~L}(+)$ arabinose (Sigma Aldrich). The Stx2B was purified by affinity chromatography using a Ni-NTA column (Qiagen). The purity and identity of the protein was checked by SDS-PAGE and Western blotting, respectively. The protein content was determined by Bradford assay using BSA as the standard protein.

\section{PREPARATION OF Stx2-SPECIFIC IgY AND IgG ANTIBODIES}

Anti-Stx2 polyclonal IgY and IgG antibodies were obtained as described in Parma et al. (2011) by immunization of hens and rabbits with recombinant Stx2B. This procedure was reviewed by the Animal Care and Use Committee at The National Institute of Agriculture Technology. Briefly, the egg yolk was physically separated from the egg white and mixed with four volumes of cold distilled water and kept at $-20^{\circ} \mathrm{C}$ for at least $72 \mathrm{~h}$ and thereafter thawed at $4^{\circ} \mathrm{C}$. The disrupted emulsion was centrifuged at $8000 \times \mathrm{g}, 15 \mathrm{~min}$ at $4^{\circ} \mathrm{C}$. The liquid phase containing the IgY was filtered through a gauze tissue and ammonium sulphate was added $(0.24 \mathrm{~g} / \mathrm{ml}$ supernatant $)$. After centrifugation at
$10,000 \times \mathrm{g}, 15 \mathrm{~min}$ at $4^{\circ} \mathrm{C}$, the pellet was dissolved with ammonium sulphate $2 \mathrm{M}$ and centrifuged again. Finally, the pellet was resuspended and dialyzed against PBS ( $\mathrm{pH} 7.4$ ) at $4^{\circ} \mathrm{C}$. For rabbit sera antibodies, blood samples were kept overnight at room temperature, sera were separated by centrifugation and thereafter stored at $-20^{\circ} \mathrm{C}$ until use. IgG was precipitated with ammonium sulphate ( $45 \%$ saturation) and stirred overnight at $4^{\circ} \mathrm{C}$. After centrifugation at $10,000 \times \mathrm{g}$ for $3 \mathrm{~min}$ at $4^{\circ} \mathrm{C}$, supernatants were discarded and pellets were dissolved and dialyzed against PBS ( $\mathrm{pH}$ 7.4). The specificity and titer of the antibodies was checked against Stx2B recombinant protein by Dot Blot and Western Blot assays. Also, the cytotoxin-neutralizing activity of anti-Stx2B IgY and IgG antibodies was assessed by incubation of $4 \mathrm{CD}_{50}$ of the holotoxin with serial dilutions of the antibodies. Preimmune antibodies were included as a negative control (Parma et al., 2011). Anti-Stx2B IgG antibodies were conjugated to horseradish peroxidase by using EZ-Link Plus activated peroxidase (Thermo Scientific).

\section{TEST SAMPLES}

The STEC strains analyzed in this study have been previously described regarding the serotype, cytotoxicity and other virulence factors (Parma et al., 2000; Padola et al., 2004; Sanz et al., 2007; Krüger et al., 2011). The 42 STEC strains were selected in order to include strains harboring different stx variants as well as different origins (feedlot cattle, grazing cattle, cattle at abattoir, ground beef, and hamburgers) (Table 1). To assess the specificity of the anti-Stx2B IgY sandwich ELISA, non-STEC strains (23 isolates) were also collected (Table 2). Supernatants were prepared from the selected strains and tested by ELISA and Vero cell assay. Briefly, bacterial cultures were grown at $37^{\circ} \mathrm{C}$ in LB medium until OD $600 \mathrm{~nm}$ reached 0.3 . The culture was then supplemented with mitomycin C $(0.5 \mu \mathrm{g} / \mathrm{ml})$ and incubated overnight. Supernatants were obtained by centrifugation of bacteria at $10,000 \times \mathrm{g}$ for $10 \mathrm{~min}$ at $4^{\circ} \mathrm{C}$. Samples were filter-sterilized and stored in aliquots at $-20^{\circ} \mathrm{C}$.

\section{PURIFICATION OF WILD TYPE StX2 HOLOTOXIN}

The supernatant of wild type Stx2 was prepared from strain 59-2 isolated from cattle (Parma et al., 2000) as in Section "Test Samples." This preparation was applied to the HiTrap NHSactivated HP (GE) column coupled with affinity purified antiStx2B IgG obtained as described previously (Parma et al., 2011). The column was washed with binding buffer $(75 \mathrm{mM}$ Tris- $\mathrm{HCl}$ $\mathrm{pH}$ 8.0) until the absorbance $(\lambda: 280 \mathrm{~nm})$ of the wash solution returned to baseline values. The Stx 2 bound to the column was eluted with three volumes of elution buffer $(100 \mathrm{mM}$ glycine, $0.5 \mathrm{M} \mathrm{NaCl} \mathrm{pH} \mathrm{2.7)} \mathrm{in} \mathrm{collection} \mathrm{tubes} \mathrm{and} \mathrm{immediately} \mathrm{neutral-}$ ized with $1 \mathrm{M}$ Tris- $\mathrm{HCl}(\mathrm{pH}$ 9.0). This procedure was repeated three times and the fractions were pooled and concentrated using an Amicon ultrafiltration unit fitted with an YM 10 membrane. The purity and concentration of Stx2 holotoxin in the eluted fraction were determined by SDS-PAGE. Briefly, recombinant Stx2B $(4.34 \mu \mathrm{g})$, Stx2 supernatant and Stx2 in the eluate $(13.5 \mu \mathrm{l}$ of each one) were separated by $12.5 \%$ SDS-PAGE and stained with Coomasie Blue. The percentage of purity and the concentration of Stx 2 were quantified by densitometry using NIH Image software 
Table 1 | STEC strains tested in this work.

\begin{tabular}{|c|c|c|c|c|}
\hline \multirow[b]{2}{*}{ Stx genotype } & \multirow[b]{2}{*}{ Serotype } & \multicolumn{3}{|c|}{ Result } \\
\hline & & Vero cell & Ridascreen-EIA & IgY-ELISA \\
\hline$s t x_{2 E D L 933}$ & O91:H21 & + & $3+$ & + \\
\hline$s t x_{2 E D L 933}$ & O145:H- & + & $4+$ & + \\
\hline$s t x_{2 E D L 933}$ & O20:H19 & + & $4+$ & + \\
\hline$s t x_{2 E D L 933}$ & O145:H- & + & $4+$ & + \\
\hline$s t x_{2 E D L 933}$ & O145:H- & + & $4+$ & + \\
\hline$s t x_{2 E D L 933}$ & O113:H21 & + & $4+$ & + \\
\hline$s t x_{2 E D L 933}$ & O113:H21 & + & $4+$ & + \\
\hline$s t x_{2 E D L 933}$ & O26:H11 & + & $4+$ & + \\
\hline$s t x_{2 E D L 933}$ & O91:H21 & + & $2+$ & + \\
\hline$s t x_{2 E D L 933}$ & O39:H49 & + & $4+$ & + \\
\hline$s t x_{2 E D L 933}$ & ONT:H21 & + & $4+$ & + \\
\hline$s t x_{2 E D L 933}$ & O39:H49 & + & $4+$ & + \\
\hline$s t x_{2 E D L 933}$ & ONT:H19 & + & $4+$ & + \\
\hline$s t x_{2 E D L 933}$ & 0145:H- & + & $4+$ & + \\
\hline$s t x_{2 E D L 933}$ & O39:H49 & + & $4+$ & + \\
\hline$s t x_{2 E D L 933}$ & O39:H49 & + & $4+$ & + \\
\hline$s t x_{2 v h a}$ & O113:H21 & + & $4+$ & + \\
\hline$s t x_{2 v h a}$ & O162:H7 & + & $4+$ & + \\
\hline$s t x_{2 v h a}$ & ONT:H21 & + & $4+$ & + \\
\hline$s t x_{2 v h a}$ & ONT:H7 & + & $4+$ & + \\
\hline$s t x_{2 v h a}$ & O113:H21 & + & $1+$ & + \\
\hline$s t x_{2 v h a}$ & $\mathrm{O} 171: \mathrm{H} 2$ & + & $2+$ & + \\
\hline$s t x_{2 v h a}$ & O117:H7 & + & $4+$ & + \\
\hline$s t x_{2 v h a}$ & O178:H19 & + & $1+$ & + \\
\hline$s t x_{2 v h b}$ & O91:H21 & + & $1+$ & + \\
\hline$s t x_{2 v h b}$ & O20:H19 & + & $3+$ & + \\
\hline$s t x_{2 v h b}$ & O79:H19 & + & $4+$ & + \\
\hline$s t x_{2 v h b}$ & O174:H21 & + & $4+$ & + \\
\hline$s t x_{2 v h b}$ & $\mathrm{O} 2: \mathrm{H}-$ & + & $2+$ & + \\
\hline$s t x_{2 v h b}$ & O171:H- & + & $4+$ & + \\
\hline$s t x_{2 v h b}$ & O117:H7 & + & $2+$ & + \\
\hline$s t x_{2 v h b}$ & O171:H2 & + & $4+$ & + \\
\hline$s t x_{2 g}$ & O15:H21 & + & - & + \\
\hline$s t x_{2 g}$ & 0175:H8 & + & - & + \\
\hline$s t x_{2 g}$ & 0175:H8 & + & - & + \\
\hline$s t x_{2 g}$ & $\mathrm{O} 2: \mathrm{H} 25$ & + & $4+$ & + \\
\hline$s t x_{1 \text { EDL933 }}$ & $\mathrm{O} 174: \mathrm{H} 21$ & + & $4+$ & + \\
\hline$s t x_{1 \text { EDL933 }}$ & O8:H16 & + & $4+$ & + \\
\hline$s t x_{1 \mathrm{EDL}} 933$ & $\mathrm{O} 5: \mathrm{H}-$ & + & $4+$ & + \\
\hline$s t x_{1}$ EDL933 & O145:H- & + & $4+$ & + \\
\hline$s t x_{1 \text { EDL933 }}$ & O26:H11 & + & $4+$ & + \\
\hline$s t x_{1 d}$ & ONT:H8 & + & $1+$ & + \\
\hline
\end{tabular}

(Image J). Then, proteins were transferred from SDS-PAGE to nitrocellulose membrane (Hybond ECL, Amersham Pharmacia Biotech) blocked overnight at $4^{\circ} \mathrm{C}$ with $5 \%$ skimmed milk in PBS-T $0.1 \%$ and incubated with a 1:200 dilution of anti-Stx2B IgY in PBS-T for $1 \mathrm{~h}$ at $37^{\circ} \mathrm{C}$. After washing, the membrane was incubated with horseradish peroxidase-conjugated goat antichicken IgY (1:4000) for $1 \mathrm{~h}$ at $37^{\circ} \mathrm{C}$. Finally, membrane was revealed using $\mathrm{DAB} / \mathrm{H}_{2} \mathrm{O}_{2}$ system. The integrity and biological activity of the holotoxin was checked by ELISA and Vero cell assay, respectively.
Table 2 | Non-STEC strains tested in this work.

\begin{tabular}{|c|c|c|}
\hline \multirow[b]{2}{*}{ Strain } & \multicolumn{2}{|c|}{ Result } \\
\hline & Vero cell & IgY-ELISA \\
\hline Proteus mirabilis & - & - \\
\hline Proteus vulgaris & - & $-{ }^{\prime}$ \\
\hline Morganella morganii & - & - \\
\hline Citrobacter freundii & - & - \\
\hline Enterococcus faecalis & - & - \\
\hline Campylobacter coli & - & - \\
\hline Shigella flexneri & - & + \\
\hline Shigella sonnei & - & - \\
\hline Campylobacter jejuni & - & - \\
\hline Staphylococcus aureus & - & - \\
\hline Enterobacter cloacae & - & - \\
\hline Salmonella typhimurium 09/63 & - & - \\
\hline Salmonella typhimurium 09/67 & - & - \\
\hline Salmonella enteritidis PT II & - & + \\
\hline Salmonella gallinarum 1982 & - & - \\
\hline Klebsiella pneumoniae & - & - \\
\hline Clostridium difficile & - & - \\
\hline Clostridium perfringens tipo $D$ & - & - \\
\hline Clostridium perfringens & - & - \\
\hline Clostridium perfringens tipo $A$ & - & - \\
\hline E. coli $\mathrm{DH} 5 \alpha$ & - & - \\
\hline Enteropathogenic E. coli & - & - \\
\hline E. coli XL1 & - & - \\
\hline
\end{tabular}

\section{ANTI-Stx2B IgY SANDWICH ELISA}

Microplates (Nunc, Maxisorp) were coated overnight at $4^{\circ} \mathrm{C}$ with a 1:500 dilution of specific IgY antibodies in carbonate/bicarbonate buffer $\mathrm{pH}$ 9.6. After washing with PBS-T 0.05\%, plates were blocked with 5\% skimmed milk in PBS-T for $1 \mathrm{~h}$ at $37^{\circ} \mathrm{C}$. Culture supernatants were diluted $1: 5$ in PBS-T and incubated at $37^{\circ} \mathrm{C}$ for $1 \mathrm{~h}$. Plates were washed and then incubated with a 1:500 dilution of horseradish peroxidase-conjugated anti-Stx2B IgG antibodies in 5\% skimmed milk -PBS-T. Plates were incubated $1 \mathrm{~h}$ at $37^{\circ} \mathrm{C}$, and after washing developed with TMB (Sigma)/peroxidase substrate solution. The reaction was stopped with $2 \mathrm{~N} \mathrm{H}_{2} \mathrm{SO}_{4}$ and absorbance was read at $450 \mathrm{~nm}$. Stx2-containing supernatant from strain 59-2 was used as a positive control. A non-STEC E. coli DH5 $\alpha$ supernatant was included as a negative control. All samples were processed by duplicate.

Receiver operating characteristic (ROC) curve analysis (MedCalc Software 8.1.0.0) was performed on the ELISA results to determine the optimal cut-off point (at which the sum of the sensitivity and specificity values is highest) for distinguishing between positive and negative results. Specimens were considered Shiga toxin positive when the optical density was $>0.26$. Test results were recorded as positive $(+)$ or negative $(-)$. The detection limit was determined with twofold serial dilutions of the purified Stx2 holotoxin and calculated from the mean $+3 \mathrm{SD}$ of the blank control. The intra-assay test was performed using three different culture supernatants (with high, medium, and 
low OD values), in replicates of six across the microplate. The inter-assay test was performed using three different culture supernatants (with high, medium, and low OD values) in duplicates repeated on three different microplates on different days. Coefficients of variation were calculated for each sample as the $\mathrm{SD} /$ mean $\times 100$.

\section{THE RIDASCREEN-EIA}

This assay (Ridascreen ${ }^{\circledR}$ Verotoxin, R-Biopharm, Germany) is provided as a kit containing a microtitre plate coated with mouse monoclonal antibodies directed against Stx1 and Stx2, as well as enzyme-conjugate, washing buffer, enzyme substrate, and stop solution. The assay was performed following the instructions of the manufacturer (http://www.r-biopharm.de/). Inactivated Stx is provided as positive and non-inoculated growth medium was taken as negative control. The cut-off value for recording results as positive was calculated by adding $0.1 \mathrm{OD}$ to the value obtained with the negative control as described for the Ridascreen-EIA. Test results were recorded as weak $(1+)$ positive if the extinction was $>0.1-0.5$ above the negative control, moderate $(2+)$ (extinction $>0.5-1.0$ above negative control), strong positive $3+(>1.0-2.0)$ to $4+(>2.0)$ and negative $(-)$.

\section{CYTOTOXICITY TEST}

African green monkey kidney (Vero) cells were plated at $10^{4} /$ well on 96-well plates in Dulbecco's Modified Eagle Medium (DMEM) containing $10 \%$ fetal bovine serum and incubated overnight at $37^{\circ} \mathrm{C}$ under $5 \% \mathrm{CO}_{2}$. Serial twofold dilutions of STEC supernatants in DMEM medium were prepared. Non-STEC supernatants were also included in order to discard the presence of Stx in species other than E. coli. Dilutions were added to the cell monolayer ( $100 \mu \mathrm{l} /$ well) and incubated for $48 \mathrm{~h}$ at $37^{\circ} \mathrm{C}$ under $5 \%$ $\mathrm{CO}_{2}$. The viability of the Vero cells was determined by crystal violet staining (Gentry and Dalrymple, 1980). All data represent the average of triplicate assays.

\section{RESULTS}

\section{IgY AND IgG ANTIBODY YIELD}

Highly purified total antibodies preparations were obtained from rabbit sera and chicken egg yolk by the ammonium precipitation method. The final concentration of total $\mathrm{IgY}$ was $0.84 \mathrm{mg} / \mathrm{ml}$ of egg yolk (equivalent to $8.4 \mathrm{mg}$ of total $\mathrm{IgY}$ per egg). The concentration of total $\mathrm{IgG}$ was $1.35 \mathrm{mg} / \mathrm{ml}$ of sera. Both polyclonal antibodies, IgY and IgG neutralized the cytotoxic effects of Stx2 holotoxin on Vero cells. However, IgG antibodies were four times more efficient than IgY antibodies, since $1.09 \mu \mathrm{g} / \mathrm{ml}$ were sufficient to neutralize the effect of the toxin in vitro, compared with IgY antibodies that obtained the same effect with $4.38 \mu \mathrm{g} / \mathrm{ml}$ (Parma et al., 2011).

\section{PURIFICATION OF StX2 HOLOTOXIN}

Densitometry analysis of the band patterns obtained by SDSPAGE, showed approximately a $20 \%$ purity of the Stx2 in the eluate (Figure 1, lane 2) representing an enrichment of $50 \% \mathrm{com}$ pared with the Stx2 in the supernatant of strain 59-2 (Figure 1, lane 3 ). Band intensity corresponding to the $2 \mathrm{~B}$ subunit from Stx2 in the eluate (Figure 1, lane 2) was compared with the one produced by a known amount of $2 \mathrm{~B}$ recombinant protein (Figure 1, lane 1) using NIH Image software (Image J). We concluded that the concentration of Stx 2 in the eluted fraction was around $75 \mu \mathrm{g} / \mathrm{ml}$. In addition, the purification procedure preserved the biological activity of the holotoxin, as this solution was cytotoxic on Vero cell monolayer.

\section{DETERMINATION OF THE DETECTION LIMIT AND THE REPRODUCIBILITY OF ANTI-Stx2B IgY SANDWICH ELISA}

Serial twofold dilutions of purified Shiga toxin were tested by the IgY sandwich ELISA to evaluate its sensitivity (Figure 2). The ELISA developed was able to detect $115 \mathrm{ng} / \mathrm{ml}$ of purified wild type Stx2. A good dose-response correlation was observed between 0.93 and $7.5 \mu \mathrm{g}$ of toxin per $\mathrm{ml}$.

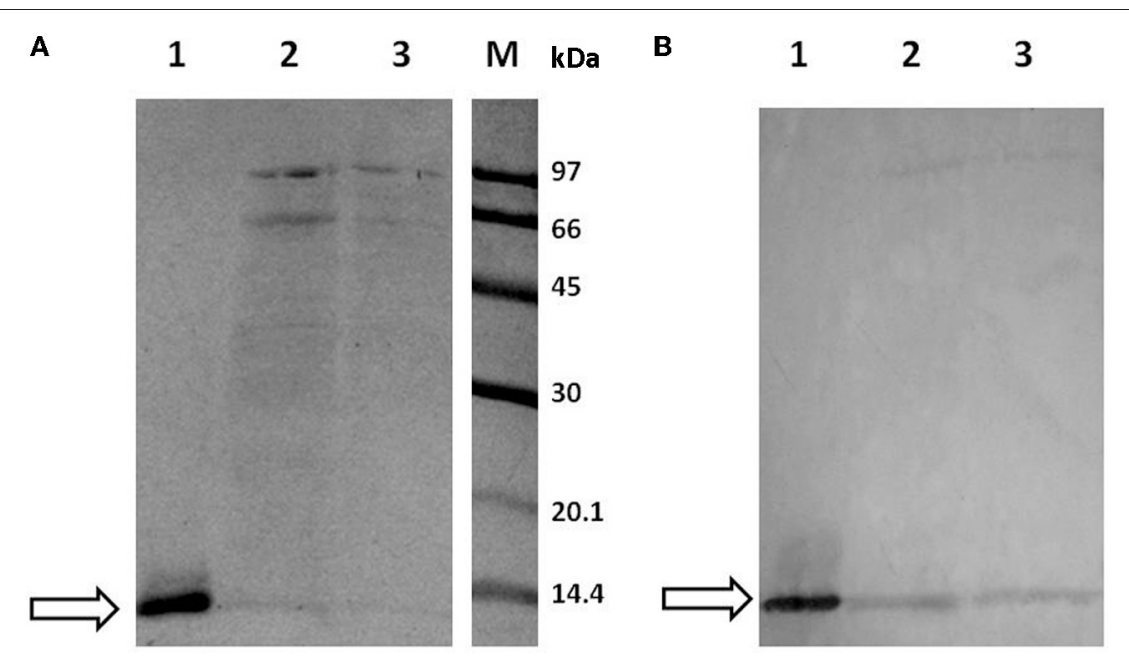

FIGURE 1 | Analysis of Stx2 holotoxin by SDS-PAGE and Western blot. (A) SDS-PAGE (12.5\% acrylamide, under reducing conditions)

Lane 1: Purified recombinant Stx2B $(4.34 \mu \mathrm{g})$ Lane 2: Stx2 holotoxin in the eluate $(13.5 \mu l)$ Lane 3: Stx2 supernatant from strain $59-2(13.5 \mu l)$. Gel was stained with Coomassie Blue. (B) Western blot Lane 1: Purified recombinant Stx2B $(4.34 \mu \mathrm{g})$ Lane 2: Stx2 holotoxin in the eluate $(13.5 \mu l)$ Lane 3: Stx2 supernatant from strain 59-2 (13.5 $\mu \mathrm{l})$. Membrane was incubated with anti-Stx2B IgY and anti-lgY HRP. Arrow: Stx2B subunit position. 


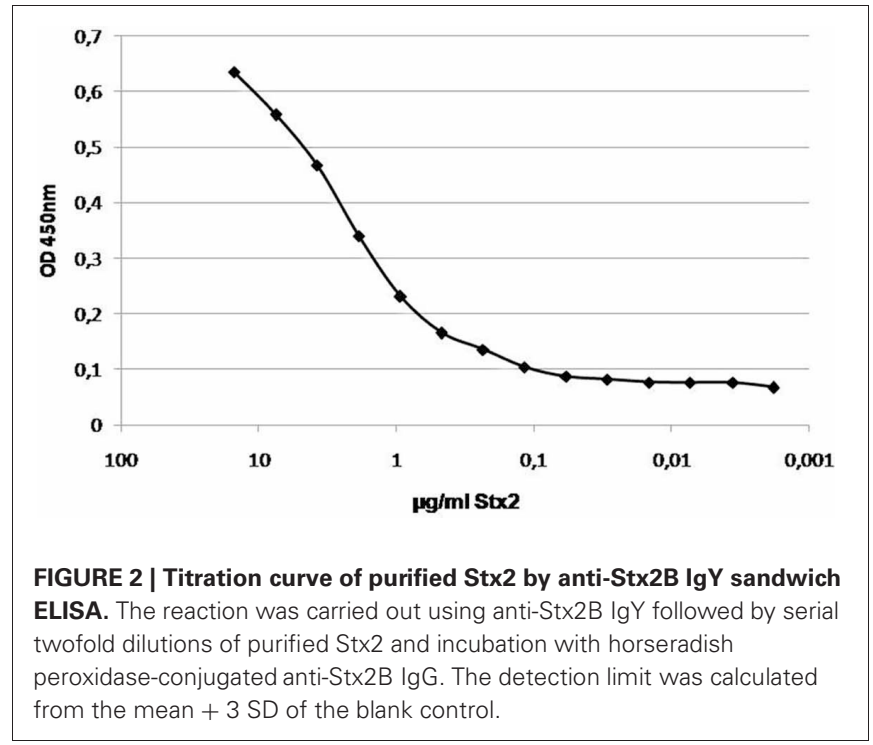

Coefficients of variation among the wells (intra-assay) ranged from 5.5 to $5.7 \%$ and coefficients of variation among the plates (inter-assay) ranged from and 3.2 to $7.7 \%$.

\section{COMPARISON OF THE PERFORMANCE OF IgY-ELISA, RIDASCREEN EIA AND VERO CELL ASSAY FOR THE DETECTION OF SHIGA TOXINS}

The IgY-ELISA assay detected all stx gene variants tested in this work: $s t x_{2 \mathrm{EDL} 933}, s t x_{2 \mathrm{vha}}, s t x_{2 \mathrm{vhb}}, s_{x_{2 \mathrm{~g}}}$, st $x_{1 \mathrm{EDL} 933}$, st $_{1 \mathrm{~d}}$ (Table 1), although IgY antibodies were prepared by immunization with recombinant Stx2B obtained from a stx 2 EDL933 variant. These samples were collected from STEC strains of various serotypes and origins. The positive results in the IgY-ELISA were in accordance to those of the Vero cell assay and the Ridascreen-EIA, with the exception of three samples containing the $s t x_{2 \mathrm{~g}}$ variant, which were negative in the Ridascreen-EIA.
Only two supernatants from a total of 23 non-STEC samples showed an OD above the cut off. These samples were negative for cytotoxicity on the Vero cell assay (Table 2).

\section{RELATIVE SENSITIVITY AND SPECIFICITY OF THE IgY-ELISA}

The relative sensitivity and specificity were determined considering the cut off value calculated by an interactive dot diagram (MedCalc Software 8.1.0.0) that divided the population into Stx-positive and Stx-negative strains (Figure 3). The relative sensitivity was defined as the number of positive strains in the assay divided by the total number of STEC strains, and resulted in $100 \%$ for the IgY-ELISA compared with $92.8 \%$ obtained with Ridascreen-EIA.

The relative specificity, defined as the number of negative strains in the assay divided by the total number of non-STEC strains, showed a percentage for IgY-ELISA of 91.3.

\section{DISCUSSION}

Chickens, as a host for the production of egg yolk antibodies against E. coli Stx2B, showed a remarkable ability to rapidly and efficiently generate an abundant supply of high-titer antibody, which is able to bind to the wild type holotoxin and also to neutralize their biological activity both in vitro and in vivo (Parma et al., 2011). The present report describes a sensitive antigen capture-ELISA for Shiga toxin which is based on antibodies produced in chicken and rabbits immunized with a purified non-toxic recombinant Stx2B subunit. All STEC strains tested in this work, which produced Stx (as confirmed by the Vero cell assay) were specifically recognized in the IgY-ELISA, although they belong to different origins and serotypes. One disadvantage of ELISA assays are false positives, in this case IgY antibodies recognized 2/23 non-STEC supernatants, one from Salmonella enteritidis and another from Shigella flexneri which showed negative results on Vero cell assay. Non-STEC supernatants were included in the cytotoxicity assay because it has been reported that other members of the family Enterobacteriaceae are known

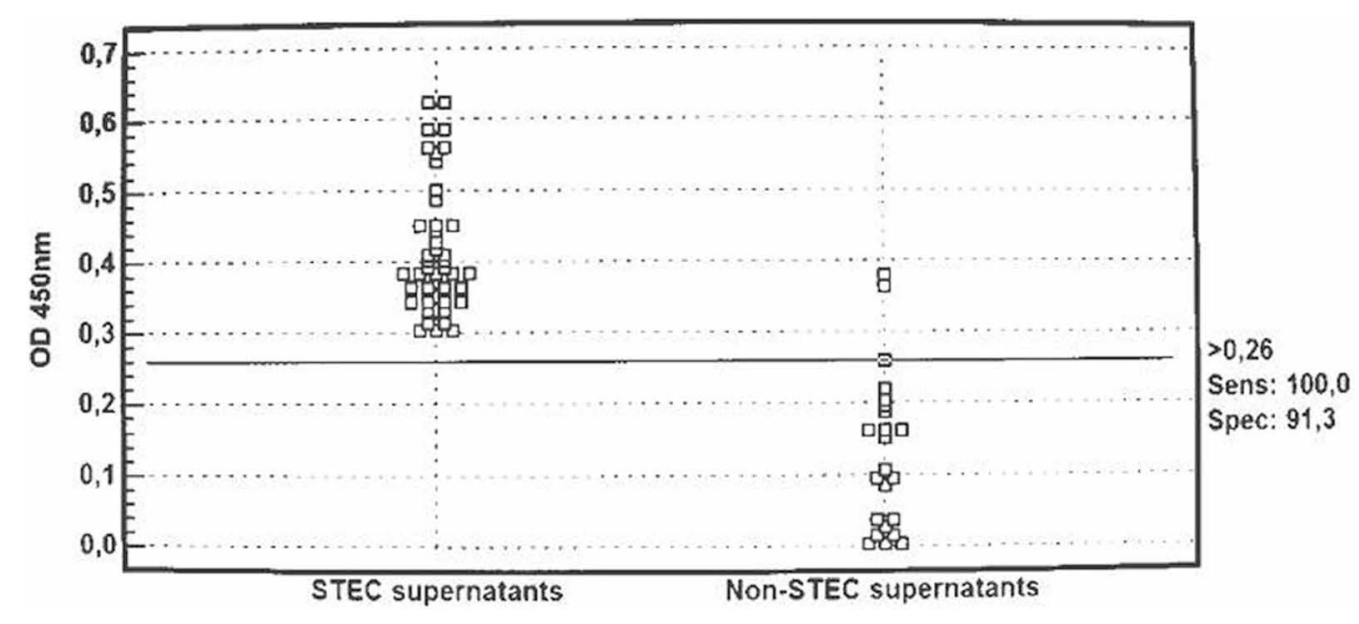

FIGURE 3 | Interactive dot diagram (MedCalc Stadistical Software). In the graph the data of the Stx-positive and Stx-negative strains are displayed as dots on two vertical axes. A horizontal line indicates the cut-off point with the best separation (minimal false negative and false positive results) between the two groups. The corresponding test characteristics sensitivity and specificity are shown at the right side of the graph. 
to produce Stx and to cause serious gastrointestinal disease and HUS in humans (Paton and Paton, 1998). S. dysenteriae type 1 , the causative agent of bacillary dysentery, is the principal cause of HUS in parts of Africa and Asia (Azim et al., 1997; Bhimma et al., 1997). Stx2-producing Citrobacter freundii also causes diarrhea and HUS in humans, including one outbreak in a German child care centre (Schmidt et al., 1993; Tschäpe et al., 1994). Enterobacter cloacae has also been associated with transient expression of an $s t x_{2}$-related gene, although its role in disease is unproven (Paton and Paton, 1996). In addition, samples containing Staphylococcus aureus can produce false positives in the ELISA since protein A binds the Fc region of IgG antibodies. This interference is not observed with IgY antibodies since they do not recognize this protein (Mizutani et al., 2012). This fact was confirmed in our lab when we run an ELISA assay with a $S$. aureus supernatant, where IgG instead of IgY was coated to the plate (data not shown).

Several ELISAs employed monoclonal antibodies, such as the Ridascreen-EIA (R-Biopharm AG, Germany) and Premier EHEC assay (Meridian Diagnostics Inc.) to improve the specificity and reduce false positives. Monoclonal antibodies being directed against single epitopes are homogeneous, highly specific and can be produced in unlimited quantities. However, producing a high quality monoclonal antibody is often difficult, laborious and expensive. Polyclonal antibodies present some advantages compared to monoclonal antibodies, as they recognize multiple epitopes on the antigen, so they become more tolerant to minor changes on their structure. Their production is relatively inexpensive, the technology and skills required for production are low, and the production time scale is comparatively short. However, the use of polyclonal antibodies has certain limitations such as batch to batch variation, inconsistent yields of antibodies and scanty serum obtained from individual animals. The IgY derived from hyperimmune chicken egg yolk has been recognized as an excellent, alternative source of polyclonal antibodies (Hodek and Stibororá, 2003). A single chicken can produce an enormous amount of antibody, up to $3 \mathrm{~g}$ of IgY per month, which is 10-20 times the amount of a rabbit (Mine and Kovacs-Nolan, 2002). Furthermore, compared to rabbits, chickens produce antibodies in shorter time periods given that high-titer antibodies can be available from eggs as early as day 25. To our knowledge, it is the most humane way to produce polyclonal antibodies because there is no need to bleed the chicken, simply collecting the eggs. In addition, we have previously described (Parma et al., 2011) that the same amount of specific anti-Stx2B antibodies can be obtained from five eggs yolks than from the exsanguination of one rabbit.

Analyzing mitomycin $\mathrm{C}$ treated cultures, we determined a relative sensitivity of $100 \%$ for the IgY-ELISA, with a detection limit of around $115 \mathrm{ng} / \mathrm{ml}$. Law et al. (1992) described that mitomycin C enhanced the yield of Shiga toxins in O157:H7 cultures about 100-fold compared with growth without mitomycin C. This group also described an ELISA with a detection limit of around $1.6 \mathrm{ng} / \mathrm{ml}$. In this case, plates were coated with crude hydatid cyst material and toxins were detected adding specific rabbit antibodies and revealed with anti-rabbit conjugated to alkaline phosphatase. Kongmuang et al. (1987) developed a sandwich ELISA for Shiga toxin detection, using antibodies from rabbits immunized with the complete inactivated toxin. This ELISA also detected several nanograms of purified Shiga toxin per milliliter. The Premier EHEC assay was found to be more sensitive than conventional sorbitol-Mac Conkey culture for the detection of E. coli O157:H7 (100 and 60\%, respectively) (Sue Kehl et al., 1997). Beutin et al. (2007) evaluated the suitability of RidascreenEIA for detection of Stx1, Stx2, and their variants with STEC reference strains and STEC isolates from sources such as food, human feces, surface water, and animal feces, resulting in a relative sensitivity and specificity of 95.7 and $98.7 \%$, respectively. However, this assay was less applicable for testing samples where low amounts of Stx are expected, such as mixed cultures or presence of $s t x_{2 g}$ variant. This fact was also observed in our work, were IgY-ELISA could detect all STEC containing $s t x_{2 g}$ variant while Ridascreen-EIA only showed positive in one of four cases.

In STEC infections, a rapid diagnosis is necessary in order to establish a proper supportive treatment. In many laboratories, diagnosis is made by fecal culture on sorbitol-Mac Conkey agar to isolate strains of E. coli serotype O157:H7 which are sorbitol non-fermenters, followed by agglutination with specific antisera. However, several drawbacks limit the utility of culture, including slow turnaround, false negative results in antibiotictreated patients, and false STEC negative results due to emerging serotypes of non-O157 STEC that ferment sorbitol (Bettelheim, 1998). Although, Vero cell assay is more sensitive than ELISA, with detection limits of around picograms per milliliter of toxin (Kongmuang et al., 1987) this assay requires that specificity of any cytotoxic activity be confirmed with appropriate neutralizing antibodies. In addition, it is a time-consuming and expensive technique. It is however essential for reference laboratories to continue to use this test, because it will reveal the presence of unknown variants of Stxs (Bettelheim and Beutin, 2003). ELISAs do offer relative speed, greater availability, are suitable for large-scale screening, and easily applicable in routine diagnostic laboratories without the need for expensive equipment.

The results of this study indicate that polyclonal IgY antibodies anti-Stx2B are a useful alternative to detect most of the variants of Shiga toxin among supernatant cultures of STEC strains belonging to different serotypes. Although further studies with clinical samples must be done, we propose the use of polyclonal IgY antibodies in order to reduce the cost of the assay in comparison to commercial kits that include monoclonal antibodies. EIA and other quick non-culture tests are useful tools for diagnosis of STEC infection, constituting an important complement to microbiological, molecular characterization and serological methods for detecting and controlling STEC outbreaks (CDC, 2009).

\section{ACKNOWLEDGMENTS}

We thank Laura Gonzalez and José Vallejo for their technical assistance. This work was supported by grants from Consejo Nacional de Investigaciones Científicas y Técnicas (CONICET) PIP100172, Fondo para la Investigación Científica y Tecnológica (FONCYT) PICT 0861/08. C. V. Granobles Velandia and Y. R. Parma are holders of fellowships from CONICET. M. E. Fernández Miyakawa, P. M. A. Lucchesi, and A. Krüger are members of the Scientific Research Career of CONICET. 


\section{REFERENCES}

Ake, J. A., Jelacic, S., and Ciol, M. A. (2005). Relative nephroprotection during Escherichia coli O157:H7 infections: association with intravenous volume expansion. Pediatrics 115, 673-680.

Ambrosius, H., and Hadge, D. (1987). Chicken immunoglobulins. Vet. Immunol. Immunopathol. 17, 57-67.

Azim, T., Ronan, A., Khan, W. A., Salam, M. A., Albert, M. J., and Bennish, M. L. (1997). "Features of Shigella-associated hemolytic uremic syndrome (HUS) in children, abstr. V187/I," in Third International Symposium and Workshop on Shiga Toxin (Verotoxin)-Producing Escherichia coli Infections (Melville, NY: Lois Joy Galler Foundation for Hemolytic Uremic Syndrome Inc.), 22.

Ball, H. J., Finlay, D., Zafar, A., and Wilson, T. (1996). The detection of verocytotoxins in bacterial cultures from human diarrhoeal samples with monoclonal antibodybased ELISAs. J. Med. Microbiol. 44, 273-276.

Bettelheim, K. A. (1998). Reliability of CHROMagar O157 for the detection of enterohaemorrhagic Escherichia coli (EHEC) O157 but not EHEC belonging to other serogroups. J. Appl. Microbiol. 85, 425-428.

Bettelheim, K. A., and Beutin, L. (2003). Rapid laboratory identification and characterization of verocytotoxigenic (Shiga toxin producing) Escherichia coli (VTEC/STEC). J. Appl. Microbiol. 95, 205-217.

Beutin, L., Gleier, K., Kontny, I., Echeverria, P., and Scheutz, F. (1997). Origin and characteristics of enteroinvasive strains of Escherichia coli (EIEC) isolated in Germany. Epidemiol. Infect. 118, 199-205.

Beutin, L., Steinrück, H., Krause, G., Steege, K., Haby, S., Hultsch, G., and Appel, B. (2007). Comparative evaluation of the Ridascreen ${ }^{\circledR}$ Verotoxin enzyme immunoassay for detection of Shiga-toxin producing strains of Escherichia coli (STEC) from food and other sources. J. Appl. Microbiol. $102,630-639$.

Beutin, L., Zimmermann, S., and Gleier, K. (1996). Pseudomonas aeruginosa can cause false-positive identification of verotoxin (Shigalike toxin) production by a commercial enzyme immune assay system for the detection of Shiga-like toxins (SLTs). Infection 24, 267-268.
Bhimma, R., Rollins, N., Coovadia, H. M., and Adhakiri, M. (1997). "Hemolytic uremic syndrome following a Shigella dysenteriae type 1 outbreak in South Africa, abstr. V208/I," in Third International Symposium and Workshop on Shiga Toxin (Verotoxin)-Producing Escherichia coli Infections (Melville, NY: Lois Joy Galler Foundation for Hemolytic Uremic Syndrome Inc.), 24.

Brooks, J. T., Sowers, E. G., Wells, J. G., Greene, K. D., Griffin, P. M. Hoekstra, R. M., and Strockbine, N. A. (2005). Non-O157 Shiga toxin-producing Escherichia coli infections in the United States 1983-2002. J. Infect. Dis. 192 1422-1429.

CDC. (2009). Recommendations for diagnosis of Shiga Toxin-Producing Escherichia coli infections by clinical Laboratories. MMWR Recomm. Rep. $58,1-14$.

Exeni, R. (2001). Síndrome urémico hemolítico. Arch. Latin. Nefr. Ped. 1, 35-56.

Friedrich, A. W., Bielaszewska, M. Zhang, W., Pulz, M., Kuczius, T., Ammon, A., and Karch, H. (2002). Escherichia coli harboring Shiga toxin 2 gene variants: frequently and association with clinical symptoms. J. Infect. Dis. 185, 74-84.

Gentry, M. K., and Dalrymple, J. M. (1980). Quantitative microtiter cytotoxicity assay for Shigella toxin. J. Clin. Microbiol. 12, 361-366.

Gerritzen, A. (1998). Comparison of two enzyme immuno assays and verocell cytotoxicity for detection of verotoxins in human feces. J. Lab. Med. 22, 704-712.

Griffin, P. M., and Tauxe, R. V (1991). The epidemiology of infections caused by Escherichia coli O157:H7, other enterohemorrhagic E.coli, and the associated hemolytic uremic syndrome. Epidemiol. Rev. 13, 60-98.

Hardin, C., Pinczes, J., Riell, A. Presutti, D., Miller, W., and Robertson, D. (2001). Cloning, Gene Expression, and Protein Purification. Oxford: Oxford University Press, 196-384.

Hodek, P., and Stibororá, M. (2003). Chicken antibodies - Superior alternative for conventional immunoglobulins. Proc. Indian Natl. Sci. Acad. 4, 461-468.

Ito, H., Terai, A., Kurazono, H., Takeda, Y., and Nishibuchi, M. (1990). Cloning and nucleotide sequencing of Vero toxin 2 variant genes from Escherichia coli O91:H21 isolated from a patient with the hemolytic uremic syndrome. Microb. Pathog. 8, 47-60.

Kongmuang, U., Honda, T., and Miwatani, T. (1987). Enzymelinked immunosorbent assay to detect shiga toxin of Shigella dysenteriae and related toxins. J. Clin. Microbiol. 25, 115-118.

Krüger, A., Lucchesi, P. M. A., and Parma, A. E. (2011). Verotoxins in bovine and meat verotoxinproducing Escherichia coli isolates: type, number of variants, and relationship to cytotoxicity. Appl. Environ. Microbiol. 77 73-79.

Larsson, A., and Sjoquist, J. (1990). Chicken IgY: utilizing the evolutionary difference. Comp. Immunol. Microbiol. Infect. Dis. 13 199-201.

Law, D., Leela Ganguli, A., DonohueRolfe, A., and Acheson, D. W. K. (1992). Detection by ELISA of low numbers of Shiga-like toxinproducing Escherichia coli in mixed cultures after growth in the presence of mitomycin C. J. Med. Microbiol. 36, 198-202.

Mine, Y., and Kovacs-Nolan, J. (2002). Chicken egg yolk antibodies as therapeutics in enteric infectious disease: a review. J. Med. Food 5 159-169.

Mizutani, N., Sugita-Konishi, Y. Omoe, K., Shinagawa, K., Kawakami, H., Kanno, S., Sugiyama, K., and Kamata, Y. (2012) Advantages of immunoglobulin $\mathrm{Y}$ for the detection of Staphylococcal enterotoxin A in a double-antibody sandwich enzyme-linked immunosorbent assay. Int. J. Food Sci. Technol. 47, 155-159.

O'Brien, A. D., and Holmes, R. K. (1987). Shiga and shigalike toxins. Microbiol. Rev. 51, 206-220.

Padola, N. L., Sanz, M. E., Blanco, J. E. Blanco, M., Blanco, J., Etcheverría, A. I., Arroyo, G. H., Usera, M. A., and Parma, A. E. (2004). Serotypes and virulence genes of bovine Shigatoxigenic Escherichio coli (STEC) isolated from a feedlot in Argentina. Vet. Microbiol. 100, 3-9.

Parma, A. E., Sanz, M. E., Blanco, J. E., Blanco, J., Viñas, M R., Blanco, M., Padola, N. L., and Etcheverría, A. I. (2000) Virulence genotypes and serotypes of verotoxigenic Escherichia coli isolated from cattle and foods in Argentina. Importance in public health. Eur. J. Epidemiol. 16, 757-762.
Parma, Y. R., Chacana, P. A., Rogé, A., Kahl, A., Cangelosi, A., Geoghegan, P., Lucchesi, P. M. A., and Fernández-Miyakawa, M. E. (2011). Antibodies anti-Shiga toxin 2 B subunit from chicken egg yolk: isolation, purification and neutralization efficacy. Toxicon 58, 380-388.

Paton, A. W., and Paton, J. C. (1996). Enterobacter cloacae producing a Shiga-like toxin II-related cytotoxin associated with a case of hemolytic uremic syndrome. J. Clin. Microbiol. 34 463-465.

Paton, J. C., and Paton, A. W. (1998). Pathogenesis and diagnosis of Shiga toxin-producing Escherichia coli infections. Clin. Microbiol. Rev. 11, 450-479.

Rivas, M., Padola, N. L., Lucchesi, P. M. A., and Massana, M. (2010). "Diarrheagenic Escherichia coli in Argentina," in Pathogenic Escherichia coli in Latin America, ed A. G. Torres (Oak Park, IL: Bentham Science Publishers Ltd.), 142-161.

Sanz, M. E., Villalobo, C., Elichiribehety, E., and Arroyo, G. H. (2007). Prevalencia de Escherichia coli verocitotoxigénico en productos cárnicos de la ciudad de Tandil. La Ind. Cárnica Lat. 146, 56-58.

Schade, R., Calzado, E. G., Sarmiento, R., Chacana, P. A., PorankiewiczAsplund, J., and Terzolo, H. R. (2005). Chicken egg yolk antibodies (IgY technology): a review of progress in production and use in research and human and veterinary medicine. Altern. Lab. Anim. 33 129-154.

Scheutz, F., Beutin, L., and Smith, H. (2001). "Clinical detection of verocytotoxin-producing $\quad E$. coli (VTEC)," in Verocytotoxigenic E. coli, eds G. Duffy, P. Garvey, and D. A. McDowell (Trumbull: Food and Nutrition Press), 25-57.

Schmidt, H., Montag, M., Bockemuhl, J., Heesemann, J., and Karch, H. (1993). Shiga-like toxin IIrelated cytotoxins in Citrobacter freundii strains from humans and beef samples. Infect. Immun. 61, 534-543.

Sue Kehl, K., Havens, P., Behnke, C. E., and Acheson, D. W. K. (1997). Evaluation of the premier EHEC assay for detection of Shiga toxin-producing Escherichia coli. J. Clin. Microbiol. 35, 2051-2054.

Tarr, P. I., Gordon, C. A., and Chandler, W. L. (2005). Shiga toxin-producing 
Escherichia coli and the haemolytic uraemic syndrome. Lancet 365, 1073-1086.

Tschäpe, H., Prager, R., Streckel, W., Fruth, A., and Böhme, G. (1994). "Outbreak of cases of hemolytic uremic syndromes and gastroenteritis in a nursery schoolverotoxinogenic Citrobacter freundii as a causative agent, abstr. O1.8," in VTEC'94: Second International Symposium and Workshop on
Verocytotoxin (Shiga-Like Toxin)Producing Escherichia coli infections (Milan: Italian Association of Clinical Microbiologists), 22.

Conflict of Interest Statement: The authors declare that the research was conducted in the absence of any commercial or financial relationships that could be construed as a potential conflict of interest.
Received: 12 April 2012; paper pending published: 24 April 2012; accepted: 29 May 2012; published online: 18 June 2012.

Citation: Parma YR, Chacana PA, Lucchesi PMA, Rogé A, Granobles Velandia $C V$, Krüger A, Parma $A E$ and Fernandez-Miyakawa ME (2012) Detection of Shiga toxin-producing Escherichia coli by sandwich enzymelinked immunosorbent assay using chicken egg yolk IgY antibodies. Front.
Cell. Inf. Microbio. 2:84. doi: 10.3389/ fcimb.2012.00084

Copyright (C) 2012 Parma, Chacana, Lucchesi, Rogé, Granobles Velandia, Krüger, Parma and FernandezMiyakawa. This is an open-access article distributed under the terms of the Creative Commons Attribution Non Commercial License, which permits noncommercial use, distribution, and reproduction in other forums, provided the original authors and source are credited. 